\title{
GC/MS and HPTLC-based Methods of Comparison among Standard and Different Commercial Samples of
}

\section{Ferula gummosa Boiss}

\author{
Mahmoodreza Moein ${ }^{1,2}$, Saeed Maalhagh-Fard ${ }^{1,2}$, Atefeh Jalali ${ }^{1,3}{ }^{(\mathbb{D}}$, Sepideh Habibzadeh ${ }^{4}$, Mohammad \\ M. Zarshenas 1, 3, 5, *(D)
Medicinal Plants Processing Research Center, Shiraz University of Medical Science, Shiraz, Iran
Department of Pharmacognosy, School of Pharmacy, Shiraz University of Medical Science, Shiraz, Iran Shiraz, Iran \\ Department of Phytopharmaceuticals (Traditional Pharmacy), School of Pharmacy, Shiraz University of Medical Sciences, \\ 4 Department of Chemistry, Payame Noor University, Tehran, Iran \\ 5 Department of Pharmacology \& Toxicology, School of Pharmacy, Shiraz University of Medical Sciences, Shiraz, Iran \\ * Correspondence: zarm@ @ums.ac.ir;
}

Received: 8.11.2020; Revised: 5.12.2020; Accepted: 6.12.2020; Published: 8.12.2020

\begin{abstract}
Ferula gummosa (Apiaceae) Boiss. as a valuable herbal medicine possesses various medical and industrial applications. The oleo-gum resin of $F$. gummosa, called Galbanum, holds several biological activities for its numerous terpenoid compounds. This study has been conducted on quality control of the $F$. gummosa oleo-gum resin prepared from standard plants, and commercial samples belong to different parts of Iran. For this purpose, essential oil and dichloromethane extracts and standard fruit essential oil were obtained and evaluated by Gas Chromatography/Mass Spectrometry (GC/MS). Moreover, all dichloromethane oleo-gum resin samples (Standards and commercials) were qualitatively analyzed by High-Performance Thin-Layer Chromatography (HPTLC). Based on the GC/MS analysis, $\beta$-Pinene, $\delta$-3-Carene and, $\alpha$-Pinene in standard and $\beta$-Pinene, $\alpha$-Pinene and, $\delta$-3Carene in essential oil, commercial samples were recognized as major compounds, respectively. The GC/MS analysis indicates that all commercial oleo-gum resin samples may obtain from the rhizome except one of them. The HPTLC analysis also revealed that the same spot pattern in all samples might be related to the major resin constituents. However, the source of oleo-gum resin could not be clarifying. Based on the results, both GC/FID and HPTLC analysis are useful methods for quality control of oleogum resin. The plant part used for oleo-resin extraction can be recognized via the percentage of essential compounds in it.
\end{abstract}

Keywords: Ferula gummosa; essential oil; HPTLC; GC/MS.

(C) 2020 by the authors. This article is an open-access article distributed under the terms and conditions of the Creative Commons Attribution (CC BY) license (https://creativecommons.org/licenses/by/4.0/).

\section{Introduction}

Essential oils have been applied since ancient times for their biological properties like antimicrobial, antioxidant, and antiseptic activities [1]. These commonly oil-soluble compounds are extracted from various plant's parts such as bark, seeds, and leaves [2, 3]. Nowadays, natural compounds' consumption as valuable medicine sources is significantly increased due to growing concern about synthetic compounds' side effects [4]. Essential oils are used for medicinal and cosmetic purposes, and in some industries like food production [5]. 
The genus Ferula as a member of the Apiaceae family possesses about 180 species that are mainly distributed in middle and west Asia. Numerous species of this genus have a pungent smell and bitter taste. Sesquiterpenes, sesquiterpene coumarins, sesquiterpene lactones, and sulfur-containing compounds are the major amounts of this genus [6-8].

Traditional Persian manuscripts (TPM), as a historically important school of medicine, provided valuable information about the prescription of herbal medicines and treatment recommendations [9, 10]. The Ferula species have been traditionally consumed for several diseases, including skin and vaginal infections, malaria, intestinal parasites, influenza, and diarrhea all over the World [11, 12], mainly, in TPM, used as an anticonvulsant, anti-flatulent, antispasmodic and expectorant properties [13]. The oleo-gum resin of Ferula has been used in paint, varnish, soap, detergent, food, and perfume industries [14].

Among about 30 related species to the Ferula genus, which are located in Iran, Ferula tabasensis, Ferula persica, and F. gummosa are endemic [15].

Ferula gummosa Boiss. is commonly known as Barije and Ghasniis in Iran [16], and in Unani is named Gaosheer and Jawaasheer. F. gummosa has tiny yellowish flowers and produces a milky white oleo-gum resin that exudes its roots and stems. These exudates are called Galbanum [17]. Galbanum possesses many terpenoids and holds various biological activities such as analgesic, laxative, carminative, digestive, aphrodisiac, expectorant, wound healing remedy, anti-convulsive, antiseptic, anti-nociceptive, anti-catarrh, anti-hysteric, antiinflammatory, antidiabetic and anti-rheumatic as well as antimicrobial activity. Also, Galbanum is applied in textiles, cosmetics, and various glues manufacturing [18, 19].

Various separation methods are used for quality control of herbal medicines [20]. The gas chromatography/mass spectrometry (GC/MS) is considered one of the most useful practical techniques for bioactive compounds analytical investigations [21]. High-performance thinlayer chromatography (HPTLC) is also applied for fingerprinting and medicinal plants' analytical quality control [22].

This study has been conducted on quality control of the $F$. gummosa oleo-gum resin prepared from standard plants, and commercial samples belong to different parts of Iran. For this purpose, essential oil and dichloromethane extract, and standard fruit essential oil were obtained and analyzed via Gas Chromatography/Mass Spectrometry (GC/MS). Each sample was qualitatively compared to the others through High-Performance Thin-Layer Chromatography (HPTLC).

\section{Materials and Methods}

\subsection{Plant Material and sample collection.}

\subsubsection{Standard samples.}

Standard oleo-gum resin samples are collected from standard F. gummosa plants cultivated in a specific medicinal plant farm (in the height of 1900 to 2000 meters from sea level) in Damavand area, Firuzkuh, north of Iran. The herbarium was authenticated by the Department of Phytopharmaceuticals, Shiraz School of Pharmacy.

The list of standard samples, sample code, sample collection method, time of collection, and plant parts are showed in Table 1. 


\subsubsection{Commercial samples.}

Five commercial samples are collected from the market. The list of samples, sample code, place, and collection time, are presented in Table 1.

Table 1. The list of standard and commercial samples.

\begin{tabular}{|c|c|c|c|c|c|}
\hline $\begin{array}{l}\text { Sample } \\
\text { Type }\end{array}$ & $\begin{array}{c}\text { Sample } \\
\text { Code }\end{array}$ & Plant Part & $\begin{array}{c}\text { Area of } \\
\text { Collection }\end{array}$ & Sample collection method & $\begin{array}{c}\text { Collection } \\
\text { time }\end{array}$ \\
\hline \multirow[t]{3}{*}{ 产 } & SS & Stem & $\begin{array}{c}\text { Damavand } \\
\text { area, Firuzkuh }\end{array}$ & $\begin{array}{l}\text { Standard plant stems }(\mathrm{n}=300) \text { were subjected to } \\
\text { direct scrapping by sharp knife within } 19 \text { days (from } \\
11 \text { am to } 4 \text { pm during the third week) }\end{array}$ & May 2020 \\
\hline & SG & Rhizome & $\begin{array}{c}\text { Damavand } \\
\text { area, Firuzkuh }\end{array}$ & $\begin{array}{l}\text { First removing the soil around of the rhizomes, } \\
\text { Standard plant rhizomes }(\mathrm{n}=70) \text { were subjected to } \\
\text { direct scrapping by sharp knife within } 16 \text { days (from } \\
11 \text { am- } 4 \text { pm during the third week) }\end{array}$ & May 2020 \\
\hline & SF & Fruit & $\begin{array}{c}\text { Damavand } \\
\text { area, Firuzkuh }\end{array}$ & Standard plant fruits were collected & June 2020 \\
\hline \multirow{5}{*}{ 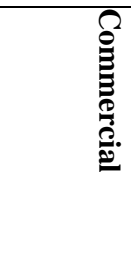 } & $\mathrm{J} 1$ & Unknown & Kashan & - & 2019 \\
\hline & $\mathrm{J} 2$ & Unknown & Firuzkuh & - & 2019 \\
\hline & $\mathrm{J} 3$ & Rhizome & $\begin{array}{c}\text { Arjomand } \\
\text { area, Firuzkuh }\end{array}$ & - & 2020 \\
\hline & $\mathrm{J} 4$ & Rhizome & Bojnurd & - & 2020 \\
\hline & J5 & Rhizome & $\begin{array}{l}\text { Taibad, North } \\
\text { Khorasan }\end{array}$ & - & 2020 \\
\hline
\end{tabular}

\subsection{Essential oil extraction and isolation.}

A particular amount of oleo-gum resin from each sample (according to table 2) and ground fruit (via miller) were weighted and soaked in a certain amount of distilled water for 24 hours. Then each sample was poured into a Clevenger apparatus and hydro distilled for 4 hours. The essential oils were dehydrated via sodium sulfate and kept in $-4^{\circ} \mathrm{C}$.

\subsubsection{Sample preparation for GC/MS analysis.}

The essential oils were diluted via dichloromethane (1:5) and dehydrated by sodium sulfate. Then $1 \mu 1$ of each sample was injected into GC/MS apparatus.

\subsubsection{GC/MS analysis.}

Agilent technology (model 7890A), coupled with a mass detector, was used for GC/MS analysis. HP-5MS capillary column (phenylmethyl siloxane, $\mathrm{L} \times \mathrm{I} . \mathrm{D} .30 \mathrm{~m} \times 0.25 \mathrm{~mm}$, with $0.25-\mu \mathrm{m}$ thickness) was employed with a carrier gas (Helium) $1 \mathrm{~mL} / \mathrm{min}$ flow rate. The oven temperature was adjusted from 60 to $220^{\circ} \mathrm{C}$ by the heating rate of $5^{\circ} \mathrm{C} / \mathrm{min}$ and then was kept at $220^{\circ} \mathrm{C}$ for 10 minutes.

The Mass spectrometer (Agilent technologies 5975C) was selected in the EI model at $70 \mathrm{eV}$, and the injected temperature was set at $280^{\circ} \mathrm{C}$. The mass range was recorded from 30 to $600 \mathrm{~m} / \mathrm{z}$. Compound recognition was based on comparing their $\mathrm{KI}$ and mass spectra with $\mathrm{nl} 7$ and Adams libraries spectra. GC/MS computed each compound percentage area in each essential oil. Normal alkane $\left(\mathrm{C}_{9}-\mathrm{C}_{24}\right)$ was used to calculate Kovats retention indices [2].

\subsection{Oleo-gum resin extraction.}

The oleo-gum resin extraction from standard and commercial samples performed by ultrasound-assisted extraction technique according to the following: 
Approximately $1 \mathrm{~g}$ of each sample and ground fruit (via miller) were mixed individually with $10 \mathrm{ml}$ of dichloromethane and sonicated for 30 seconds at room temperature. The samples were dried at $30^{\circ} \mathrm{C}$ for 10 minutes in Petri dishes after filtration. Dried extracts were sealed tightly and kept at room Temperature for HPTLC analysis. Dried and pre-weighed Petri dishes of each sample were used to yielded total oleo-gum resin extract.

\subsubsection{Sample preparation for HPTLC analysis.}

$10 \mathrm{mg}$ of each dried dichloromethane sample was diluted via dichloromethane and shake well. Then 5 and $10 \mu 1$ of each sample was applied to HPTLC analysis.

\subsubsection{HPTLC analysis.}

HPTLC analysis was carried out using the CAMAG TLC system coupled with an automatic developing chamber (ADC2) and ATS 4 (automatic TLC sample 4). ATS4 apparatus loads samples by nitrogen gas under 5 bar pressure. Silica gel plate $60 F 254(10 \times 10 \mathrm{~cm}$, Merck, Germany) used as stationary phase, and a mobile phase (solvent system) in the ADC2 apparatus was Toluene: Ethyl acetate $(3: 1 ; \mathrm{v} / \mathrm{v})$. Band length was $6 \mathrm{~mm}$, and the application mode was spray band. Distance from both $\mathrm{X}$ and $\mathrm{Y}$-axis was $15 \mathrm{~mm}$, and inter-track space was $11.6 \mathrm{~mm}$. The drying time was $1 \mathrm{~min}$, and the migration distance was $80 \mathrm{~mm}$, and the mobile phase volume was $10 \mathrm{ml}$.

Seven prepared samples (SG, SS, J1, J2, J3, J4, and J5, except SF) were injected on the HPTLC plate with two loading volumes (5 and $10 \mu \mathrm{l})$.

Eventually, ultraviolet lamps (at 254 and $365 \mathrm{~nm}$, visible light) and anisaldehydesulfuric acid reagent were employed to visualizing the chromatographic spots.

\subsection{Chemicals.}

All chemicals used to carry out this study were purchased as the analytical grade from Merck (Germany) or Sigma Aldrich (USA). These chemicals are listed as follows: Acetic acid, Anisaldehyde, Dichloromethane, Ethanol 96\%, Ethyl acetate, Methanol, Sodium sulfate, and Sulfuric acid as well as Toluene.

\section{Results and Discussion}

\subsection{Essential oil and ole-gum resin extraction.}

Essential oil and ole-gum resin extraction yield of each sample are presented in table 2 with details.

Table 2. Essential oil and oleo-gum resin extraction yield.

\begin{tabular}{l|l|l|l|l}
\multirow{2}{*}{ Sample Code } & Essential oil & Oleo-gum resin \\
\cline { 2 - 5 } & Sample Weight $(\mathrm{g})$ & Yield (v/w) \% & $\begin{array}{l}\text { Dried Oleo-gum resin } \\
\text { extract Weight }(\mathrm{g})\end{array}$ & Yield (w/w) \% \\
\hline SS & 15 & 22.0 & 0.29 & 29 \\
\hline SG & 15 & 26.6 & 0.44 & 44 \\
\hline SF & 25 & 5.2 & 0.12 & 6 \\
\hline J1 & 15 & 29.3 & 0.36 & 36 \\
\hline J2 & 25 & 32.8 & 0.29 & 29 \\
\hline J3 & 24 & 27.9 & 0.28 & 28 \\
\hline J4 & 25 & 32.0 & 0.29 & 29 \\
\hline J5 & 25 & 23.6 & 0.31 & 31
\end{tabular}




\subsection{GC/MS analysis.}

Essential oil components were recognized based on GC/MS analysis and Adam's reference and respective articles about $F$. gummosa and other Ferula spp. A list of identified compounds in each sample is presented in Table 3 [23-41].

Table 3. Essential oil and oleo-gum resin extraction yield.

\begin{tabular}{|c|c|c|c|c|c|c|c|c|c|c|}
\hline No & Compound & $\mathbf{K I}$ & SF & SG & SS & J1 & $\mathbf{J} 2$ & $\mathbf{J 3}$ & J4 & J5 \\
\hline 1 & $\alpha$-Thujene & 928 & 4.65 & 1.95 & 1.38 & - & 1.41 & 0.91 & 0.39 & 2.2 \\
\hline 2 & $\alpha$-Pinene & 937 & 12.71 & 9.45 & 9.83 & 8.03 & 6.44 & 6.47 & 13.79 & 6.96 \\
\hline 3 & Sabinene & 976 & - & - & - & - & - & - & - & - \\
\hline 4 & $\beta$-Pinene & 987 & 46.6 & 38.52 & 45.52 & 53.99 & 51.83 & 45.1 & 35.48 & 32.49 \\
\hline 5 & $\beta$-Myrecene & 994 & 2.9 & 2.96 & 3.4 & 2.78 & 3.32 & 2.52 & 4.89 & 2.16 \\
\hline 6 & $\alpha$-Phellandrene & 1008 & - & - & - & - & - & - & - & 0.69 \\
\hline 7 & $\delta$-3-Carene & 1015 & 12.95 & 11.83 & 13.35 & 7.98 & 5.47 & 4.68 & 9.03 & 5.06 \\
\hline 8 & $\alpha$-Terpinene & 1021 & - & - & - & - & - & - & - & 0.93 \\
\hline 9 & O-Cymene & 1027 & 0.94 & - & 0.58 & 0.59 & 2.29 & 1.07 & 1.56 & 1.18 \\
\hline 10 & Limonene & 1031 & 1.47 & 3.28 & 3.71 & 1.47 & - & - & - & - \\
\hline 11 & $\beta$-Phellandrene & 1033 & - & - & - & - & 4.16 & 3.87 & 4.57 & 2.29 \\
\hline 12 & Z- $\beta$-Ocimene & 1037 & 0.65 & 0.97 & 0.77 & - & - & 0.64 & 1.64 & 0.71 \\
\hline 13 & (E)- $\beta$-Ocimene & 1048 & - & - & - & - & - & - & 0.7 & 0.35 \\
\hline 14 & $\gamma$-Terpinene & 1060 & - & - & - & - & - & - & 0.67 & 2.06 \\
\hline 15 & Cis Sabinene hydrate & 1070 & - & - & - & - & - & - & - & 0.63 \\
\hline 16 & Terpinolene & 1091 & - & 0.72 & 0.46 & - & - & - & 1.28 & 1.16 \\
\hline 17 & Trans-Sabinene Hydrate & 1102 & - & - & - & - & - & - & - & 0.82 \\
\hline 18 & Trans-Pinocarveol & 1142 & 0.97 & - & - & 1.4 & 1 & - & - & - \\
\hline 19 & $\begin{array}{l}1,3,5- \\
\text { Undecatriene(3E,5Z) }\end{array}$ & 1175 & - & 2.33 & 1.26 & - & - & 1.25 & 1.47 & 0.84 \\
\hline 20 & 1,3,5-Undecatriene(E,E) & 1184 & - & 0.48 & - & - & - & - & - & - \\
\hline 21 & Terpin-4-ol & 1184 & - & - & - & - & - & - & - & 3.26 \\
\hline 22 & Myrtenol & 1200 & 1.09 & 0.43 & - & 1.59 & 1.08 & 0.52 & - & - \\
\hline 23 & Fenchyl acetate & 1223 & - & 0.64 & 0.78 & - & 2.08 & 1.56 & 1.81 & 1.01 \\
\hline 24 & Thymyl methyl ether & 1237 & - & - & - & - & 1.05 & 0.78 & 0.67 & 0.4 \\
\hline 25 & Carvacrol methyl ether & 1247 & - & - & - & - & 4.06 & 3.23 & 3.18 & 1.49 \\
\hline 26 & Perilla alcohol & 1310 & 0.56 & - & - & - & - & - & - & - \\
\hline 27 & Terpin-4-ol acetate & 1341 & - & - & - & 0.6 & - & - & - & - \\
\hline 28 & $\alpha$-Terpinyl acetate & 1353 & 1.38 & 0.86 & 0.77 & 1.24 & 1.72 & 1.48 & 1.27 & 0.69 \\
\hline 29 & $(+)$-Cycloisosativene & 1373 & - & - & - & - & - & 0.46 & - & - \\
\hline 30 & $\alpha$-Copaene & 1381 & - & - & - & - & 0.65 & 0.55 & - & 0.33 \\
\hline 31 & $\beta$-Elemene & 1391 & - & - & - & - & 0.59 & 0.5 & - & 0.35 \\
\hline 32 & $\beta$-Cedrene & 1420 & 0.76 & - & - & - & - & - & - & - \\
\hline 33 & $\begin{array}{l}\text { 2,5-Dimethoxy-para } \\
\text { Cymene }\end{array}$ & 1426 & - & - & - & - & 0.68 & 0.78 & 0.73 & 0.55 \\
\hline 34 & $\beta$-Caryophyllene & 1426 & 0.6 & 0.51 & 0.58 & - & - & - & - & - \\
\hline 35 & $\gamma$-Elemene & 1438 & - & 0.51 & - & - & - & - & - & - \\
\hline 36 & $\alpha$-Caryophyllene & 1458 & 1.15 & 0.53 & 0.52 & - & - & - & - & - \\
\hline 37 & $\begin{array}{l}\text { Muurola-4-(14),5- } \\
\text { diene<cis> }\end{array}$ & 1454 & - & - & - & - & - & - & - & 2.4 \\
\hline 38 & Longifolene V1 & 1455 & - & - & - & - & 0.78 & 0.75 & - & - \\
\hline 39 & $\gamma$-Selinene & 1456 & - & - & - & - & - & - & - & 0.6 \\
\hline 40 & $\begin{array}{l}\text { (+)-Epi- } \\
\text { bicyclosesquiphellandrene }\end{array}$ & 1486 & - & - & - & - & - & - & 0.68 & - \\
\hline 41 & Germacrene-D & 1485 & 0.78 & 2.98 & 1.78 & - & - & 1.89 & 0.58 & 6.44 \\
\hline 42 & $\gamma$-Muurolene & 1481 & - & - & - & 0.6 & - & - & - & - \\
\hline 43 & Valencene & 1488 & - & - & - & - & - & - & - & 0.59 \\
\hline 44 & $\alpha$-Selinene & 1490 & - & - & 1 & - & - & - & - & - \\
\hline 45 & $\beta$-Selinene & 1492 & - & - & - & - & 0.56 & - & - & - \\
\hline 46 & Bicyclogermacrene & 1502 & - & - & - & - & - & - & 1.27 & - \\
\hline 47 & 7-Epi- $\alpha$-Selinene & 1504 & - & - & - & - & - & - & - & 1.86 \\
\hline 48 & $\beta$-Bisabolene & 1512 & 0.97 & 0.67 & 0.64 & - & - & - & - & - \\
\hline 49 & $\gamma$-Cadinene & 1520 & 0.94 & 0.71 & 0.6 & 1.26 & 0.73 & 0.57 & 0.48 & 1.7 \\
\hline 50 & $\delta$-Cadinene & 1530 & - & 1.22 & 0.81 & - & 0.53 & 0.79 & 0.63 & 3 \\
\hline 51 & Selina-3,7(11)-diene & 1554 & - & - & - & - & - & - & - & 0.48 \\
\hline 52 & Germacrene-B & 1564 & 1.91 & 3.37 & 2.28 & - & - & - & - & - \\
\hline
\end{tabular}




\begin{tabular}{|c|c|c|c|c|c|c|c|c|c|c|}
\hline No & Compound & KI & SF & SG & SS & J1 & $\mathbf{J} 2$ & J3 & J4 & J5 \\
\hline 53 & Germacrene-D-4-ol & 1582 & - & 0.49 & - & 0.74 & - & - & - & - \\
\hline 54 & Spathulenol & 1584 & - & - & - & - & - & - & 0.43 & - \\
\hline 55 & Guaiol & 1604 & 1.07 & 2.17 & 2.28 & 2.262 & 2.28 & 5.89 & 3.03 & 2.41 \\
\hline 56 & 1-Epi Cubenol & 1622 & - & - & - & 0.68 & - & - & - & 0.48 \\
\hline 57 & $\gamma$-Eudesmol & 1630 & - & 1.55 & - & - & - & - & 0.71 & - \\
\hline 58 & $\alpha$-Muurolol & 1646 & - & - & - & - & 0.87 & - & 0.56 & - \\
\hline 59 & Epi $-\alpha-$-Cadinol & 1647 & - & 0.67 & 0.48 & - & - & - & - & - \\
\hline 60 & $\alpha$-Cadinol & 1649 & - & - & - & - & - & 0.76 & - & 2.11 \\
\hline 61 & $\beta$-Eudesmol & 1658 & 0.68 & 2.02 & 0.9 & 2.95 & - & 0.95 & 0.51 & - \\
\hline 62 & $\alpha$-Eudesmol & 1660 & 0.64 & 2.03 & 1.1 & 1.75 & - & - & 0.49 & - \\
\hline 63 & 7-Epi - $\alpha$-Eudesmol & 1662 & - & - & - & - & - & - & - & 0.7 \\
\hline 64 & $\alpha$-Bisabolol & 1670 & - & - & - & - & - & - & - & 0.66 \\
\hline 65 & Bulnesol & 1678 & 0.64 & 4.44 & 5.22 & 2.03 & 2.18 & 7.26 & 3.64 & 3.57 \\
\hline \multirow[t]{6}{*}{66} & Guaiol acetate & 1725 & 0.78 & - & - & 0.58 & 0.56 & 1.54 & 0.97 & 0.74 \\
\hline & Known Compounds (\%) & & 97.79 & 98.92 & 100 & 92.52 & 96.32 & 96.77 & 97.84 & 96.35 \\
\hline & $\begin{array}{l}\text { Oxygenated } \\
\text { Monoterpinoids (\%) }\end{array}$ & & 4 & 1.93 & 1.55 & 4.83 & 11.67 & 8.35 & 7.66 & 8.85 \\
\hline & $\begin{array}{l}\text { Non-oxygenated } \\
\text { Monoterpene }(\%)\end{array}$ & & 82.87 & 70.30 & 79.00 & 74.84 & 74.92 & 65.26 & 74.73 & 58.24 \\
\hline & $\begin{array}{l}\text { Oxygenated } \\
\text { Sesquiterpene (\%) }\end{array}$ & & 4.41 & 13.88 & 10.56 & 10.99 & 5.89 & 16.40 & 11.61 & 10.67 \\
\hline & $\begin{array}{l}\text { Non-oxygenated } \\
\text { Sesquiterpene }(\%)\end{array}$ & & 6.51 & 9.99 & 7.63 & 1.86 & 3.84 & 5.51 & 2.37 & 17.75 \\
\hline
\end{tabular}

According to table 3, more than $92 \%$ of total compounds in all samples were identified.

\subsubsection{Major compounds.}

The major compounds, which are more than 5\%, and their incidence in each sample have been presented in table 4.

Table 4. List of the major compound and their incidence in both commercial and standard samples.

\begin{tabular}{l|l|l|l|l|l|l|l|l|l} 
No & Major Compound $>$ \%5 & SF & SG & SS & J1 & J2 & J3 & J4 & J5 \\
\hline 1 & a-Pinene & $\mathbf{1 2 . 7 1}$ & $\mathbf{9 . 4 5}$ & $\mathbf{9 . 8 3}$ & $\mathbf{8 . 0 3}$ & $\mathbf{6 . 4 4}$ & $\mathbf{6 . 4 7}$ & $\mathbf{1 3 . 7 9}$ & $\mathbf{6 . 9 6}$ \\
\hline 2 & $\boldsymbol{\beta}$-Pinene & $\mathbf{4 6 . 6}$ & $\mathbf{3 8 . 5 2}$ & $\mathbf{4 5 . 5 2}$ & $\mathbf{5 3 . 9 9}$ & $\mathbf{5 1 . 8 3}$ & $\mathbf{4 5 . 1}$ & $\mathbf{3 5 . 4 8}$ & $\mathbf{3 2 . 4 9}$ \\
\hline 3 & d-3-Carene & $\mathbf{1 2 . 9 5}$ & $\mathbf{1 1 . 8 3}$ & $\mathbf{1 3 . 3 5}$ & $\mathbf{7 . 9 8}$ & $\mathbf{5 . 4 7}$ & 4.68 & $\mathbf{9 . 0 3}$ & $\mathbf{5 . 0 6}$ \\
\hline 4 & Germacrene-D & 0.78 & 2.98 & 1.78 & - & - & 1.89 & 0.58 & $\mathbf{6 . 4 4}$ \\
\hline 5 & Guaiol & 1.07 & 2.17 & 2.28 & 2.62 & 2.28 & $\mathbf{5 . 8 9}$ & 3.03 & 2.41 \\
\hline 6 & Bulnesol & 0.64 & 4.44 & $\mathbf{5 . 2 2}$ & 2.03 & 2.18 & $\mathbf{7 . 2 6}$ & 3.64 & 3.57
\end{tabular}

According to table 4, the major constituent in all samples was $\beta$-Pinene. The second and third main compounds in standard samples were $\boldsymbol{\delta}$-3-Carene and $\alpha$-Pinene, respectively.

The $\delta$-3-Carene was the second main compound in all commercial samples, except J3. Bulnesol is the second major compound detected in J3, which can be regarded as one of SS's main compounds.

The third major component in $\mathrm{J} 1, \mathrm{~J} 2$, and $\mathrm{J} 4$ samples were $\delta$-3-Carene. In $\mathrm{J} 3$ and $\mathrm{J} 5$, the third major compound was $\alpha$-Pinene and Germacrene-D, respectively. The Germacrene-D could not be detected in $\mathrm{J} 1$ and $\mathrm{J} 2$ and regarded as a major compound in SS and SG and detected in a negligible amount in SF and $\mathrm{J} 4$.

Based on Table 4, all commercial samples seem to be obtained from F. gummosa oleogum resin. Among commercial samples, only J3 seems to be yielded from the plant's stem, while others seem to be prepared from the rhizome. 
3.2.2. Monoterpenoids and sesquiterpenoids.

Monoterpenoids and sesquiterpenoids were identified in all samples. The percentage of oxygenated and non-oxygenated monoterpenoids and sesquiterpenoids have been presented in table 3.

Monoterpene compounds were detected as the main essential oil portion, and among them, non-oxygenated monoterpenes were dominant. The SF, J2 also J4 contained most monoterpene composition, respectively. The SF, SS, and J2 possess the maximum amount of non-oxygenated monoterpenes.

Sesquiterpenes as other terpenic groups were identified in all samples. The most significant amount of sesquiterpenes were detected in the SG, J3, and J5, respectively. Although oxygenated sesquiterpenes were the main sesquiterpenes in all samples except SF and J5, non-oxygenated sesquiterpenes were the foremost in SF and J5. The maximum quantity of oxygenated sesquiterpenes detected in $\mathrm{J} 3, \mathrm{SS}$, and $\mathrm{J} 4$, and the maximum amount of nonoxygenated sesquiterpenes was detected in J5, SG, and SF, respectively.

\subsubsection{Hydrocarbon compounds.}

The 1, 3, 5-Umdecatriene (3E, 5Z) as the hydrocarbon compound was detected in the SG (2.33\%), SS (1.26\%), J3 (1.25\%), J4 (1.47\%) and in J5 (0.84\%). Furthermore 1, 3, 5,Undecatriene (E, E) was identified in SG $(0.48 \%)$. According to table 3, the hydrocarbon compounds could not be detected in SF, J1, and J2.

\subsection{HPTLC analysis}

Figures 1 to 3 are related to the HPTLC plate at $254 \mathrm{~nm}, 366 \mathrm{~nm}$, and visible light, respectively.

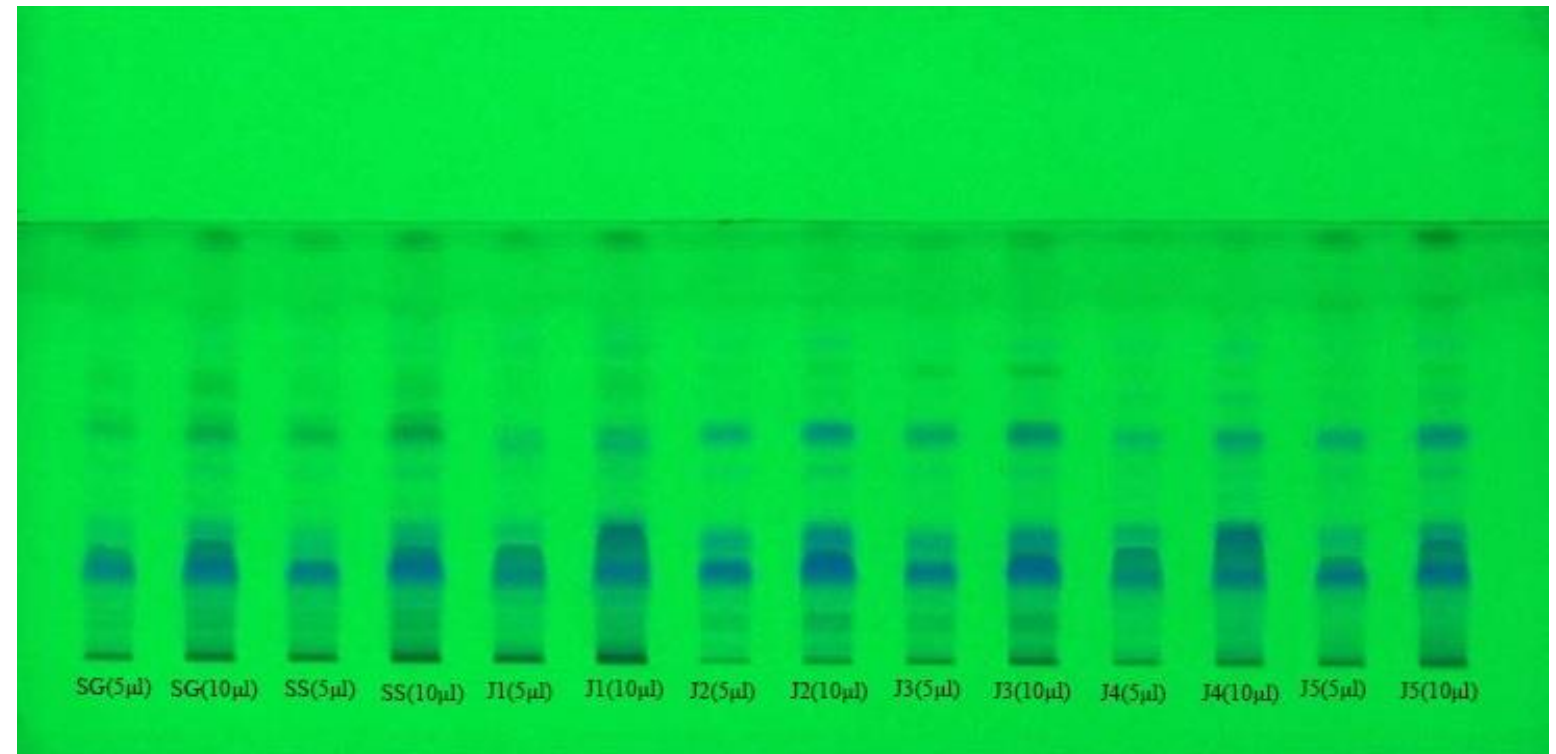

Figure 1. High-Performance Thin Layer Chromatography (HPTLC) profile of oleo-gum resin dichloromethane samples, derivatized in UV light before application of anise aldehyde reagent $(254 \mathrm{~nm})$. 


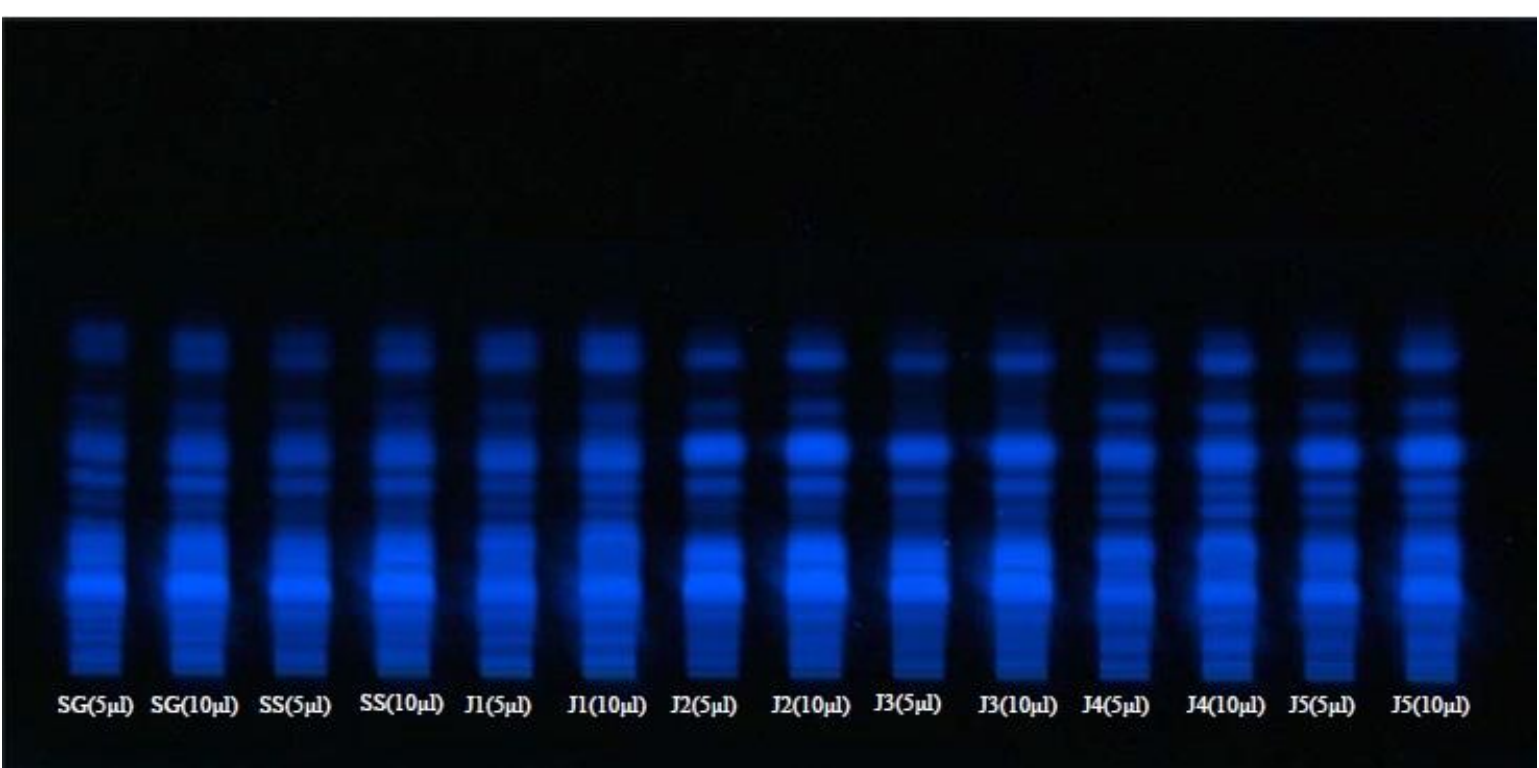

Figure 2. High-Performance Thin Layer Chromatography (HPTLC) profile of oleo-gum resin dichloromethane sample, derivatized in UV light before application of anise aldehyde reagent $(366 \mathrm{~nm})$.

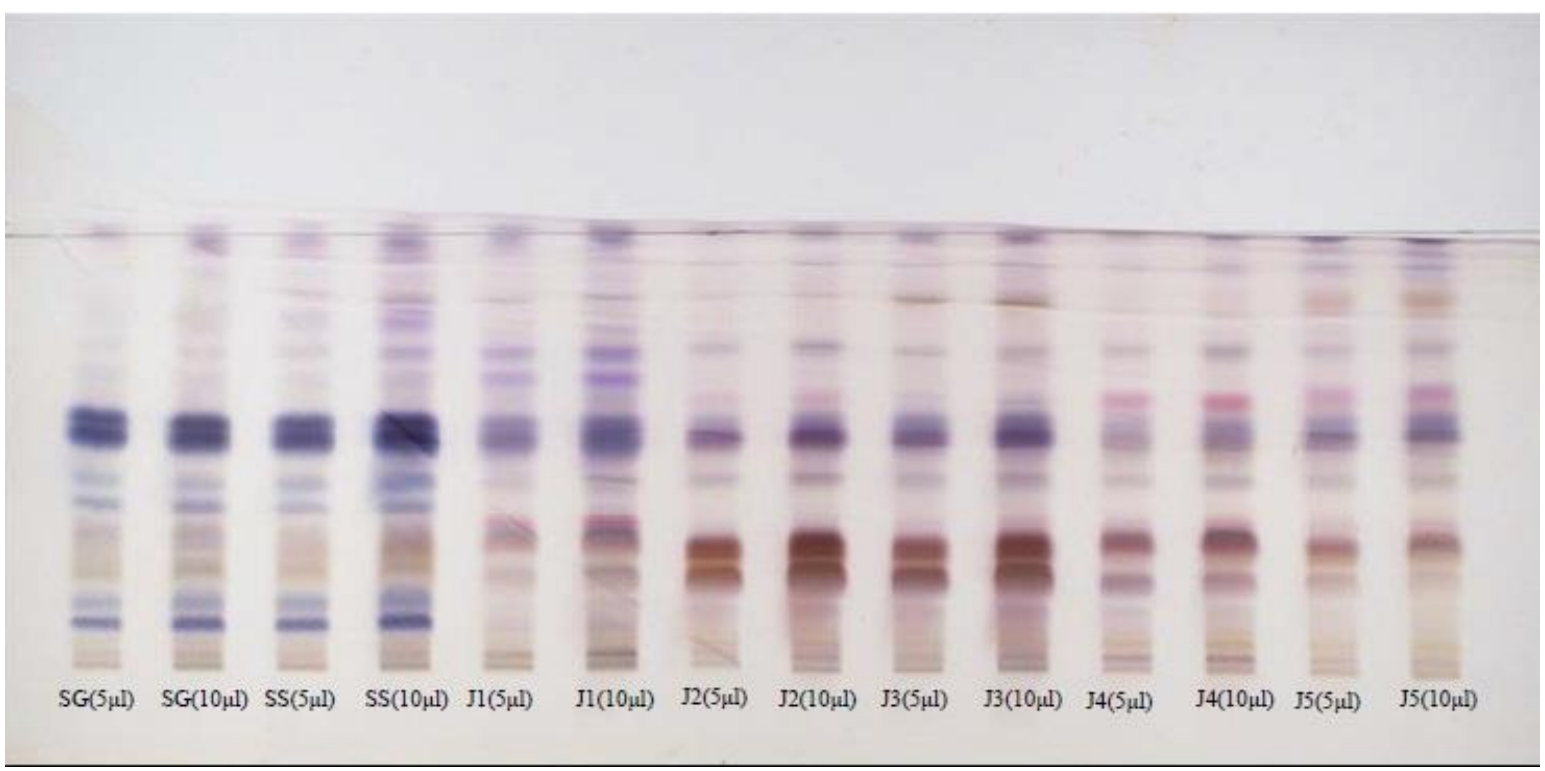

Figure 3. High-Performance Thin Layer Chromatography (HPTLC) profile of samples oleo-gum resin dichloromethane sample, derivatized in visible light after application of anise aldehyde reagent.

Based on the above figures all of the major resin constituents of samples appeared in colorful and wide bands in $\mathrm{R}_{\mathrm{f}}=0.20, \mathrm{R}_{\mathrm{f}}=0.32, \mathrm{R}_{\mathrm{f}}=0.53$ and $\mathrm{R}_{\mathrm{f}}=0.56$. According to the different colors of the $\mathrm{J} 1$ and standard samples from another commercial sample in $\mathrm{R}_{\mathrm{f}}=0.32$, the compound might not be the same in SS, SG, and J1 with J2-J5.

Based on the similar components patterns of commercial samples to HPTLC analysis standards, commercial samples were yielded from $F$. gummosa. The oleo-gum resin source could not be clarifying via the HPTLC method since the oleo-gum resin stem and rhizome have the same composition pattern.

\section{Conclusions}

F. gummosa as an important endemic plant of Iran, possesses various industrial and medical indications. Hence, designed the quality control processes are necessary for developing its usage in medicine and industry. This study has been conducted on plant sample 
identification based on their major compounds via GC/MS and HPTLC methods. In the current study, oleo-gum resin yielded from the stem and rhizome of standard $F$. gummosa was compared to five oleo-gum resin samples from Iran commercial market. All these samples were obtained from different areas of Iran. The standard and commercial oleo-gum resins and essential oils were yielded and compared. In addition to the essential oil analysis, the dichloromethane extracts of standard and commercial oleo-gum resin were analyzed through the HPTLC method. Their constituent patterns were compared.

The $\beta$-Pinene was the major compound in all standard and commercial samples in our studies. Based on this, we can declare that all commercial oleo-gum resin was obtained from $F$. gummosa, and $\beta$-Pinene can be introduced as the main compound for quality control of $F$. gummosa oleo-gum resin.

Although the $\alpha$-Pinene, $\beta$-Pinene and, $\delta$-3-Carene were the major compounds in all standard and commercial samples, the $\delta$-3-Carene was not found in J3. Also, Bulnesol was one of the major compounds in J3 and SS was the negligible amount in other samples. Then, all commercial samples, except J3, seem to be obtained from the rhizome and, J3 was prepared from the stem.

Based on the results, GC/MS and HPTLC methods can be introduced as acceptable quality controls for sample identification and recognition of plant parts used for oleo-resin extraction through the percentage of the important compounds. Secondary metabolites can be targeted for developing other quality control studies in the future.

\section{Funding}

This research received no external funding.

\section{Acknowledgments}

The authors of this manuscript wish to express their thanks to the Shiraz University of Medical Sciences.

\section{Conflicts of Interest}

The authors declare no conflict of interest.

\section{References}

1. Van de Vel, E.; Sampers, I.; Raes, K. A review on influencing factors on the minimum inhibitory concentration of essential oils. Critical reviews in food science and nutrition 2019, 59, 357-378, https://doi.org/10.1080/10408398.2017.1371112.

2. Zarshenas, M.M.; Samani, S.M.; Petramfar, P.; Moein, M. Analysis of the essential oil components from different Carum copticum L. samples from Iran. Pharmacognosy research 2014, 6, https://doi.org/10.4103/0974-8490.122920.

3. Ghavam, M.; Manca, M.L.; Manconi, M.; Bacchetta, G. Chemical composition and antimicrobial activity of essential oils obtained from leaves and flowers of Salvia hydrangea DC. ex Benth. Scientific Reports 2020, 10, 1-10, https://doi.org/10.1038/s41598-020-73193-y.

4. Jalali, A.; Kiafar, M.; Seddigh, M.; Zarshenas, M.M. Punica granatum as a Source of Natural Antioxidant and Antimicrobial Agent; a Comprehensive Review on Related Investigations. Current drug discovery technologies 2020, https://doi.org/10.2174/1570163817666200430001822.

5. Hanif, M.A.; Nisar, S.; Khan, G.S.; Mushtaq, Z.; Zubair, M. Essential oils. In: Essential Oil Research. Springer: 2019; pp 3-17, https://doi.org/10.1007/978-3-030-16546-8_1.

6. Mohammadhosseini, M.; Venditti, A.; Sarker, S.D.; Nahar, L.; Akbarzadeh, A. The genus Ferula: Ethnobotany, phytochemistry and bioactivities-A review. Industrial crops and products 2019, 129, 350394, https://doi.org/10.1016/j.indcrop.2018.12.012. 
7. Salehi, M.; Naghavi, M.R.; Bahmankar, M. A review of Ferula species: Biochemical characteristics, pharmaceutical and industrial applications, and suggestions for biotechnologists. Industrial Crops and Products 2019, 139, https://doi.org/10.1016/j.indcrop.2019.111511.

8. Baykan, Ş.; Aydoğan, F.; Öztürk, M.B.; Debeleç-Bütüner, B.; Yengin, Ç.; Öztürk, B. Ferutinin content and cytotoxic effects of various Ferula L. Species on prostate cancer (PC-3) cell line. J. Res. Pharm. 2020, 142149, https://doi.org/10.35333/jrp.2020.120.

9. Petramfar, P.; Moein, M.; Samani, S.M.; Tabatabaei, S.H.; Zarshenas, M.M. Trachyspermum ammi $10 \%$ topical cream versus placebo on neuropathic pain, a randomized, double-blind, placebo-controlled trial. Neurological Sciences 2016, 37, 1449-1455, https://doi.org/10.1007/s10072-016-2600-3.

10. Mozaffarpur, S.A.; Naseri, M.; Kamalinejad, M.; Shams, M.A.; Memariani, Z.; Moeini, R.; Gorji, N.; Moradi Farahani, A.; Shirafkan, H. Nine Steps to Discover New Medicines from Traditional Sources: The Example of Persian Medicine. The Journal of Alternative and Complementary Medicine 2020, 26, 365-368, https://doi.org/10.1089/acm.2019.0377.

11. Boghrati, Z.; Iranshahi, M. Ferula species: a rich source of antimicrobial compounds. Journal of Herbal Medicine 2019, 16, https://doi.org/10.1016/j.hermed.2018.10.009.

12. Youssef, F.S.; Mamatkhanova, M.A.; Mamadalieva, N.Z.; Zengin, G.; Aripova, S.F.; Alshammari, E.; Ashour, M.L. Chemical Profiling and Discrimination of Essential Oils from Six Ferula Species Using GC Analyses Coupled with Chemometrics and Evaluation of Their Antioxidant and Enzyme Inhibitory Potential. Antibiotics 2020, 9, https://doi.org/10.3390/antibiotics9080518

13. Bagheri, S.M.; Sahebkar, A.; Gohari, A.R.; Saeidnia, S.; Malmir, M.; Iranshahi, M. Evaluation of cytotoxicity and anticonvulsant activity of some Iranian medicinal Ferula species. Pharmaceutical biology 2010, 48, 242-246, https://doi.org/10.3109/13880200903081796.

14. Jalali, H.T.; Ebrahimian, Z.J.; Evtuguin, D.V.; Neto, C.P. Chemical composition of oleo-gum-resin from Ferula gummosa. Industrial Crops and Products 2011, 33, 549-553, https://doi.org/10.1016/j.indcrop.2010.10.032.

15. Jalali, H.T.; Petronilho, S.; Villaverde, J.J.; Coimbra, M.A.; Domingues, M.R.M.; Ebrahimian, Z.J.; Silvestre, A.J.; Rocha, S.M. Deeper insight into the monoterpenic composition of Ferula gummosa oleogum-resin from Iran. Industrial Crops and Products 2012, 36, 500-507, https://doi.org/10.1016/j.indcrop.2011.11.001.

16. Jalili-Nik, M.; Soukhtanloo, M.; Javanshir, S.; Jahani Yazdi, A.; Esmaeilizadeh, M.; Jafarian, A.H.; Ghorbani, A. Effects of ethanolic extract of Ferula gummosa oleo-resin in a rat model of streptozotocininduced diabetes. Res Pharm Sci 2019, 14, 138-145.

17. Mahboubi, M. Ferula gummosa, a Traditional Medicine with Novel Applications. Journal of Dietary Supplements 2016, 13 , 700-718, http://dx.doi.org/10.3109/19390211.2016.1157715.

18. Fatemikia, S.; Abbasipour, H.; Saeedizadeh, A. Phytochemical and Acaricidal Study of the Galbanum, Ferula gumosa Boiss. (Apiaceae) Essential Oil Against Tetranychus urticae Koch (Tetranychidae). Journal of Essential Oil Bearing Plants 2017, 20, 185-195, https://doi.org/10.1080/0972060X.2016.1257957.

19. Hamedi, H.; Kargozari, M.; Shotorbani, P.M.; Mogadam, N.B.; Fahimdanesh, M. A novel bioactive edible coating based on sodium alginate and galbanum gum incorporated with essential oil of Ziziphora persica: The antioxidant and antimicrobial activity, and application in food model. Food hydrocolloids 2017, 72, 3546, https://doi.org/10.1016/j.foodhyd.2017.05.014.

20. Farhadi, F.; Soltani, S.; Saberi, S.; Iranshahi, M. A qHNMR method for simultaneous quantification of terpenoids from Ferula ovina (Boiss.) Boiss roots. Journal of Pharmaceutical and Biomedical Analysis 2019, 172, 120-125, https://doi.org/10.1016/j.jpba.2019.04.039.

21. Beale, D.J.; Pinu, F.R.; Kouremenos, K.A.; Poojary, M.M.; Narayana, V.K.; Boughton, B.A.; Kanojia, K.; Dayalan, S.; Jones, O.A.H.; Dias, D.A. Review of recent developments in GC-MS approaches to metabolomics-based research. Metabolomics 2018, 14, https://doi.org/10.1007/s11306-018-1449-2.

22. Ebrahimi-Najafabadi, H.; Kazemeini, S.S.; Pasdaran, A.; Hamedi, A. A novel similarity search approach for high-performance thin-layer chromatography (HPTLC) fingerprinting of medicinal plants. Phytochemical Analysis 2019, 30, 405-414, https://doi.org/10.1002/pca.2823.

23. Utegenova, G.A.; Pallister, K.B.; Kushnarenko, S.V.; Özek, G.; Özek, T.; Abidkulova, K.T.; Kirpotina, L.N.; Schepetkin, I.A.; Quinn, M.T.; Voyich, J.M. Chemical composition and antibacterial activity of essential oils from Ferula L. species against methicillin-resistant Staphylococcus aureus. Molecules 2018, 23, https://doi.org/10.3390/molecules23071679.

24. Eser, N.; Yoldas, A. Identification of heat-resistant chemical components of Ferula elaeochytris root extracts by gas chromatographymass spectrometry. Tropical Journal of Pharmaceutical Research 2019, 18, 55-60, https://doi.org/10.4314/tjpr.v18i1.9.

25. Farhadi, F.; Iranshahi, M.; Taghizadeh, S.F.; Asili, J. Volatile sulfur compounds: The possible metabolite pattern to identify the sources and types of asafoetida by headspace GC/MS analysis. Industrial Crops and Products 2020, 155, https://doi.org/10.1016/j.indcrop.2020.112827.

26. Hassanabadi, M.; Ebrahimi, M.; Farajpour, M.; Dejahang, A. Variation in essential oil components among Iranian Ferula assa-foetida L. accessions. Industrial Crops and Products 2019, 140, https://doi.org/10.1016/j.indcrop.2019.111598. 
27. Tabari, M.A.; Youssefi, M.R.; Nasiri, M.; Hamidi, M.; Kiani, K.; Alian Samakkhah, S.; Maggi, F. Towards green drugs against cestodes: Effectiveness of Pelargonium roseum and Ferula gummosa essential oils and their main component on Echinococcus granulosus protoscoleces. Veterinary Parasitology 2019, 266, 8487, https://doi.org/10.1016/j.vetpar.2018.12.019.

28. Niazmand, R.; Razavizadeh, B.M. Ferula asafoetida: chemical composition, thermal behavior, antioxidant and antimicrobial activities of leaf and gum hydroalcoholic extracts. Journal of Food Science and Technology 2020, 1-12, https://doi.org/10.1007/s13197-020-04724-8.

29. Deveci, E.; Tel-Çayan, G.; Duru, M.E. Essential Oil Composition, Antioxidant, Anticholinesterase and Antityrosinase Activities of Two Turkish Plant Species: Ferula elaeochytris and Sideritis stricta. Natural Product Communications 2018, 13, https://doi.org/10.1177/1934578X1801300130.

30. Ahmadi Koulaei, S.; Hadjiakhoondi, A.; Delnavazi, M.R.; Tofighi, Z.; Ajani, Y.; Kiashi, F. Chemical composition and biological activity of Ferula aucheri essential oil. Research Journal of Pharmacognosy 2020, 7, 21-31, https://doi.org/10.22127/RJP.2020.210354.1537.

31. Boyom, F.F.; Ngouana, V.; Zollo, P. H. A.; Menut, C.; Bessiere, J.M.; Gut, J.; Rosenthal, P.J. Composition and anti-plasmodial activities of essential oils from some Cameroonian medicinal plants. Phytochemistry 2003, 64, 1269-1275, https://doi.org/10.1016/j.phytochem.2003.08.004.

32. Cheng, S.-S.; Liu, J.-Y.; Huang, C.-G.; Hsui, Y.-R.; Chen, W.-J.; Chang, S.-T. Insecticidal activities of leaf essential oils from Cinnamomum osmophloeum against three mosquito species. Bioresource Technology 2009, 100, 457-464, https://doi.org/10.1016/j.biortech.2008.02.030.

33. Ghannadi, A.; Amree, S. Volatile oil constituents of Ferula gummosa Boiss. from Kashan, Iran. Journal of Essential Oil Research 2002, 14, 420-421, https://doi.org/10.1080/10412905.2002.9699908.

34. He, M.; Yan, J.; Cao, D.; Liu, S.; Zhao, C.; Liang, Y.; Li, Y.; Zhang, Z. Identification of terpenoids from Ephedra combining with accurate mass and in-silico retention indices. Talanta 2013, 103, 116-122, https://doi.org/10.1016/j.talanta.2012.10.018.

35. Jalali-Heravi, M.; Zekavat, B.; Sereshti, H. Characterization of essential oil components of Iranian geranium oil using gas chromatography-mass spectrometry combined with chemometric resolution techniques. Journal of Chromatography A 2006, 1114, 154-163, https://doi.org/10.1016/j.chroma.2006.02.034.

36. Javidnia, K.; Miri, R.; Kamalinejad, M.; Edraki, N. Chemical composition of Ferula persica Wild. essential oil from Iran. Flavour and fragrance journal 2005, 20, 605-606, https://doi.org/10.1002/ffj.1496.

37. Kanani, M.R.; Rahiminejad, M.R.; Sonboli, A.; Mozaffarian, V.; Kazempour Osaloo, S.; Nejad Ebrahimi, S. Chemotaxonomic significance of the essential oils of 18 Ferula species (Apiaceae) from Iran. Chemistry \& biodiversity 2011, 8, 503-517, https://doi.org/10.1002/cbdv.201000148.

38. Mothana, R.A.; Al-Rehaily, A.J.; Schultze, W. Chemical analysis and biological activity of the essential oils of two endemic Soqotri Commiphora species. Molecules 2010, 15, 689-698, https://doi.org/10.3390/molecules15020689.

39. Okoh, O.; Sadimenko, A.; Afolayan, A. The effects of age on the yield and composition of the essential oils of Calendula officinalis. JApSc 2007, 7, 3806-3810, https://doi.org/10.3923/jas.2007.3806.3810.

40. Santos Filho, F.C.; da Silva Amaral, L.; Rodrigues-Filho, E. Composition of essential oils from Cupressus lusitanica and a Xylariaceous fungus found on its leaves. Biochemical systematics and ecology 2011, 39, 485-490, https://doi.org/10.1016/j.bse.2011.07.001.

41. Sylvestre, M.; Pichette, A.; Longtin, A.; Nagau, F.; Legault, J. Essential oil analysis and anticancer activity of leaf essential oil of Croton flavens L. from Guadeloupe. Journal of Ethnopharmacology 2006, 103, 99102, https://doi.org/10.1016/j.jep.2005.07.011. 